\title{
The Tax Penalty on Married Workers
}

\author{
NANCY AMMON JINAKOPLOS
}

OHN Doe and Jane Smith each earned \$15,000 in 1976 and each paid $\$ 2,403$ in Federal personal income taxes. ${ }^{1}$ The Internal Revenue Service collected $\$ 4,806$ from John and Jane. If John and Jane had been married dwring 1976, however, they would have jointly paid $\$ 6,092$ in Federal income taxes. Getting married would have cost John and Jane $\$ 1,286$ in additional 1976 Federal income taxes. This example points out one of the peculiarities of the present Federal income tax structure; under certain circumstances two working people would pay more taxes if they are married than if they are single.

Dealing equitably with households of different sizes, marital status, and number of working family members has been a problem for tax law writers. Even without referring to the economic theory of taxation, however, it is possible to examine the factors which contribute to a possible tax penalty on married workers. The consequences and possible remedies for this apparently inequitable treatment of households can also be considered.

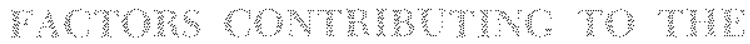

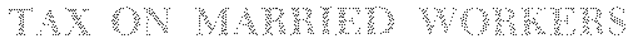

The task of specifying all possible household situations where a marriage penalty (or benefit) occurs is very difficult, and is not a very rewarding exercise. However, the fundamental characteristics of the situation remain if a few simplifying assumptions are made:

1) the standard deduction is used by all taxpayers;

2) all income is derived from wages and/or salaries;

3) all married couples file joint returns;

4) household adjusted gross incomes are $\$ 30,000$ or less; and

5) household members have no children.

While these assumptions are limiting, all except the last assumption are fairly widespread. Even the exclusion of children from the example is not that unusual. In March 1976, 15 percent of all husband-wife households were childless and both spouses were employed. ${ }^{2}$ With regard to the other assumptions, analy-

1This assumes that they used the standard deduction, clained no depentents, and all income was derived from wages or salaries.

2" "Typical' Family Not So Typical," St. Louts Post-Dispatch, March 14, 1977, For a discussion of the effects of children on the tax penalty on married workers, see Joyce M. Nissbaum, sis of 1973 tax returns indicates that 65 percent of all returns ntilized the standard deduction. ${ }^{3}$ Wages and salaries represented 83 percent of adjusted gross in comes in 1973 and 95 percent of all married couples filed joint returns. The Internal Revenue Service reported that 96 percent of all taxpayers in 1976 had adjusted gross incomes below $\$ 30,0004^{4}$

The basis for calculations of the tax penalty on married workers is the comparison of tax liabilities of a man and woman, holding constant everything except their marital status. This is not a frivolous exercise when consideration is given to the employment statistics dealing with married couples. According to March 1976 data, there were 47.3 million husbandwife families. ${ }^{5}$ In 22.3 million ( 47 percent) of these households both husband and wife worked outside the home. Full-time working wives contributed 39 percent of family income in 1976. Furthermore, the alternative of a man and woman living together without being legally married has been increasingly adopted. The number of households where unrelated adults of the opposite sex shared living quarters doubled between 1970 and 1976, although constituting only 1 percent of all households in $1976 .^{6}$

The marital status of two hypothetical people, John and Jane, for the entire tax year of 1976 is based on their marital status on December 31, 1976. There is one technicality involved with this. The Internal Revenue Service states:

If you obtain a foreign divorce for the sole pur pose of enabling you and your spouse to qualify as unmarried individuals eligible to fle separate returns, and if you then remarry each other early in the next tax year, you and your spouse must file as married individuals. ${ }^{7}$

"The Tax Structure and Discrimination Against Working Wives," National Tax Journal (June 1972), pp. 183-191.

31973 is the most recent year for which detailed analysis are published. Internal Revenue Service, Statistics of Income 1973, Individual Income Tax Returns (Washington, D.C.: Govemment Printing Office, 1976), p. 41.

Information obtaned from the Internal Revente Service in Washington, D.C.

": "Typical Family Not So Typical."

"U.S. Bureat of the Census, "Martal Status and Living Arrangenents: March 1976" Current Population Reports, Series P.20, No. 306 (Washington, D.C.: Government Printing Office, 1977), pp. $4-5$.

Intemal Revenue Service, Publication 17, Your Federal Income Tax - 1977 Edition (Washington, D.C.: Government Printing Ofice, 1977), p. 13. 


\section{ECONOMIC CONCEPTS OF TAXATION}

Among the characteristios of taxes which are generally considered desirable, are two features of par ticular mportance in evaluating the effect of taxes on households. Taxes should be equitable or fair among households and nettral towards most economic deci sions 1 Defining these terms however, is no easy matter $1 \mathrm{n}$ economic theory two types of equity are usually defned - vertieal eduity and horizontal equity. Vertical equity is defined to mean that tax payng mits, such as nutwdunls or households, with greater incomes shotld pay more taxes than units with. less income, By horizontal equity we mean, inits of equal hoome should pay equal taxes

These simple recipes, once agam, contam terms which are not easty defined, What is the appropriate taxpaying unt Is it the legal recipient of the income or the whole household which is supported by the income $\mathrm{F}$ or example, consider three possible households:

\begin{tabular}{|c|c|}
\hline House hold & Income \\
\hline$M r A$ & $\$ 30,000$ \\
\hline $\mathrm{Mrs} \mathrm{A}$ & 0 \\
\hline Total Household A & $\$ 30,000$ \\
\hline$M+B$ & $\$ 15,000$ \\
\hline Mrsa & $\$ 15,000$ \\
\hline Total Household $B$ & $\$ 30,000$ \\
\hline $\mathrm{MrC}$ & $\$ 30,000$ \\
\hline Total Household $C$ & $\$ 30,000$ \\
\hline
\end{tabular}

Ir household A Mr A makes $\$ 30,000$ a year, while Mrs A stays at home (and maybe raises a famly) In household $\mathrm{B}, \mathrm{Mr}, \mathrm{B}$ earns $\$ 15,000$ as does Mrs, B, In household $\mathrm{C}$, there is only $\mathrm{Mr}$. C, who earns $\$ 30,000$. How much tax should each household pay?

If the appropriate taxing unit is the individual income earner, Mr. A and Mr. C should pay the same

1For a more complete discussion of the desirable aspects of taxes and actual characteristics of taxes, see Richard and Peggy Musgrave, Public Finance in Theory and Practice

Even the Internal Revenue Service apparently recognizes the possible benefits of filing as single taxpayers.

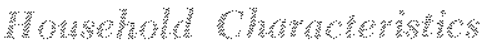

Table I shows the tax penalties and benefits of marriage in 1976 for John and Jane, given the simplifying assumptions. To use this table, select any combination of the two adjusted gross incomes which equals $\$ 30,000$ or less. Follow the horizontal line representing Jane's income to the right until it intersects with the vertical column corresponding to John's income. If the rumber at the intersection is negative, John and Jane must pay that amount in additional taxes Mre and Mrs B should each pay less fax which together miglt not equal the taxes pad by Mr $A$ or $\mathrm{Mr} \mathrm{C}$ If the appropriate taxing unit is the household, then it on be argued that all three households should pay the same anount of taxes Under 1976 tax laws Mr. C pays the most taxes, Mr and Mrs B pay less taxes, and Mr, and Mrs $A$ pay the least taxes; assuning all other crumstances are equal.

The other term which presents diffenly in determining equitable tax treatment is the definition of income The oncept of ncome is frequently dealt with in terms of ability to pay "Thus households with the same dollar noone, but of different sizes and different expenses incurred in eaning ho meome, have different abilites to pay Gumenty households are allowed a cettan amount of income exenpt from taxation tor each member of the household fpersonal exemptions, which dan be justifled as a measure of the differing abilties to pay of different sized households Furthemore, the cost of eaming income can wary from household to household For example, the expenses moured 15 onl one menber of the household is employed outside the home will usually be less than if two menbers of the same houselold work For this reason the deducton of child care expenses cain be rationalized as a measure of differing expenses incurred in eaming inoome and hence, difering ablities to pay among households.

The term neutralify, applied to the concept of taxes, means that tax provisions should be chosen to mininize friterference in market decisions, such as whether to work or how to spend ncome However there are tax provisions which explicitly promote certain behavior Tax preferences reduce income subject to taxation, for example, if the household contributes to charity, buys a house, or invests in new business equipment Apparenty, these are activities which society finds beneficial and promotes through tax preferences (deductions).

(New York: MeGraw-Hill Gonpany, 1973).

Federal taxes if they are married, rather than single. If the number is positive, John and Iane would benefit from a tax saving of that amount if they are married, rather than single. For example, if Jane makes $\$ 10,000$ and John makes $\$ 12,000$, they pay $\$ 483$ more taxes if they are married than if they are single. In contrast, if Jane makes $\$ 15,000$ and John makes $\$ 1,000$, they save $\$ 339$ in taxes by getting married. ${ }^{s}$

The outlined area of the table indicates those combinations of incomes which are associated with a tax

sThis neglects the loss of any welfare payments or eamed income tax credits john would lose by marying Jane. 
Table: 1

\section{TAX PENALTIES AND BENEFITS FOR MARRIED WORKERS}

\begin{tabular}{|c|c|c|c|c|c|c|c|c|c|c|c|c|c|c|c|}
\hline $\begin{array}{c}\text { Jane's } \\
\text { Adjusted } \\
\text { Gross } \\
\text { Income } \\
\text { (Dollars) }\end{array}$ & & & & & & & & & & & & & & & \\
\hline 30,000 & 1,701 & & & & & & & & & & & & & & \\
\hline 29,000 & 1,618 & 1,258 & & & & & & & & & & & & & \\
\hline 28,000 & 1,566 & 1,218 & 858 & & & & & & & & & & & & \\
\hline 27,000 & 1,486 & 1,166 & 818 & 499 & & & & & & & & & & & \\
\hline 26,000 & 1,406 & 1,086 & 766. & 459 & 254 & & & & & & & & & & \\
\hline 25,000 & 1,329 & 1,009 & 689 & 410 & 217 & 22 & & & & & & & & & \\
\hline 24,000 & 1,264 & 949 & 629 & 350 & 185 & 2 & +190 & & & & & & & & \\
\hline 23,000 & 1,158 & 878 & 563 & 28.4 & 119 & -36 & -216 & -396 & & & & & & & \\
\hline 22,000 & 1,078 & 798 & 518 & 244 & 79 & -76 & -228 & -396 & -566 & & & & & & \\
\hline 21,000 & 1,002 & 722 & 442 & 203 & 43 & -112 & -264 & -404 & -562 & -716 & & & & & \\
\hline 20,000 & 932 & 662 & 382 & 143 & 18 & -132 & -284 & -424 & -554 & -696 & -836 & & & & \\
\hline 19,000 & 847 & 597 & 327 & 88 & -37 & -152 & -299 & 439 & -569 & -683 & -811 & 957 & & & \\
\hline 18,000 & 787 & 537 & 287 & 58 & -67 & -182 & -294 & -429 & $\begin{array}{l}-559 \\
-546\end{array}$ & $\begin{array}{l}-673 \\
-660\end{array}$ & $\begin{array}{r}-773 \\
-760\end{array}$ & on & 1,085 & $-1,156$ & \\
\hline 16,000 & 625 & $\begin{array}{l}415 \\
339\end{array}$ & $\begin{array}{l}190 \\
129\end{array}$ & $\begin{array}{l}-19 \\
-55\end{array}$ & $\begin{array}{l}-114 \\
-150\end{array}$ & $\begin{array}{l}-219 \\
-235\end{array}$ & $\begin{array}{r}-331 \\
-337\end{array}$ & $\begin{array}{l}-43 ! \\
-437\end{array}$ & $\begin{array}{r}-521 \\
-527\end{array}$ & -601 & -696 & -802 & -920 & $-1,024$ & $-1,142$ \\
\hline $\begin{array}{l}14,000 \\
13,000\end{array}$ & $\begin{array}{l}486 \\
454\end{array}$ & $\begin{array}{l}310 \\
256\end{array}$ & 80 & -66 & -121 & $-|8|$ & -263 & -333 & -413 & -487 & 547 & -613 & -726 & -830 & -920 \\
\hline $\begin{array}{l}13,000 \\
12,000\end{array}$ & 446 & $238:$ & 40. & -95 & -127 & -172 & -229 & -290 & -359 & -423 & -483 & -549 & -627 & -726 & -816 \\
\hline 11.000 & 426 & 244 & 36 & -121 & -142 & -164 & -206 & -251 & -311 & -355 & 405 & -471 & -549 & 613 & -698 \\
\hline 10,000 & 382 & 212 & 30 & -137 & -180 & -191 & -210 & $-2 \Delta n$ & -375 & -310 & -240 & 405 & tos & $5+7$ & -397 \\
\hline 9,000 & 332 & 102 & -8 & -149 & -202 & -235 & -243 & -250 & -270 & -289 & $\quad 319$ & -355 & -423 & 487 & -537 \\
\hline 8,000 & 296 & 126 & -44 & -173 & -200 & -243 & -273 & -269 & -266 & -270 & -275 & -311 & -359 & -413 & -468 \\
\hline 7,000 & 265 & 106 & -64 & -193 & $-20 B$ & -225 & -265 & -283 & -269 & -250 & -240 & -25 & -299 & -333 & -373 \\
\hline 6,000 & 247 & 85 & -7.4 & -203 & -218 & -223 & -237 & $-2 \times 5$ & 273 & 243 & 2.10 & 206 & -228 & -203 & -283 \\
\hline 5,000 & 233 & 79 & -83 & 201 & -216 & -221 & -223 & -225 & -243 & -235 & -19 & -164 & -172 & -18.1 & -201 \\
\hline 4,000 & 196 & 68 & 86 & 207 & -211 & -210 & 218 & -208 & -200 & -202 & $\cdots 180$ & -142 & -127 & -121 & -116 \\
\hline 3,000 & 41 & 41 & -87 & -200 & -207 & -201 & -203 & -193 & -173 & -149 & -137 & -121 & -95 & -66 & -46 \\
\hline 2,000 & 0 & 0 & 0 & -87 & $-8 A$ & -83 & -74 & 61 & 41. & 6 & 30 & 50 & 40 & 80 & 123 \\
\hline 1.000 & 0 & 0 & 0 & 41 & 68 & 79 & 85 & 106 & 126 & 162 & 212 & 244 & 238 & 258 & 316 \\
\hline \multirow[t]{3}{*}{0} & 0 & 0 & 0 & 41 & 196 & 233 & 247 & 265 & 298 & 332 & 382 & $420^{\circ}$ & 446 & 454 & $48 d$ \\
\hline & 0 & $\$, 000$ & 2,000 & 3,000 & 4,000 & 5.000 & 6.000 & 7.000 & $8.00 n$ & 0.000 & 10,000 & 1,000 & 12,000 & 10.000 & 14,000 \\
\hline & & & & & & & & & & & & \multicolumn{4}{|c|}{$\begin{array}{l}\text { Lohn's Adiusted Gross Income } \\
\text { (Dollars) }\end{array}$} \\
\hline
\end{tabular}

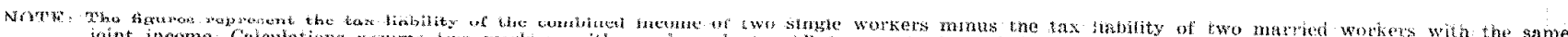
detuction aud 1970 individual tax credit.

penalty on marriage, under the assumptions uoed herc. As the numbers indicate, the penalty is a function of the size of combined income and the degres of equality between the two incomes. This means that the closer Janes income is to John's income and/or the more John and Jane earn, the larger is the tax penaly on marrage sine the fax penalty increases with the size ot combined income, increases in incone which merely represent increases due to inflation increase the ax penalty on maried workers:"

"Nuncy Jianaloplos, "Paying Nore Taxes and Aftording to Letss." this Retiete (July 1975), plo. 9-1.3.
Aware of the family chancteristics which contribute to the marrage penalty, one can examine the specific: provisions of the tax structure which produce this result. Table II compares and contrasts how John's and Jane's taxes are calculated when each is single and when lloy we muried. In both cases, their ad justed gross incomes ( $A C l$ ) are $\$ 15,000$ ach. Th they are married, their joint income equals 830,000 . A first step in tax momputation is to doduot thei: poworal exemption allowances. As single taxpayers, fohn and Janc are each entitled to a $\$ 750$ personal excmption.

lage 14: 


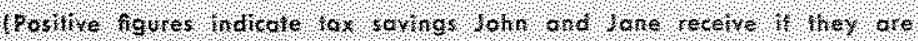

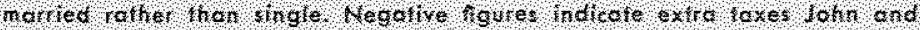

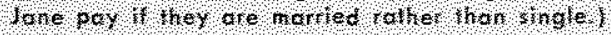

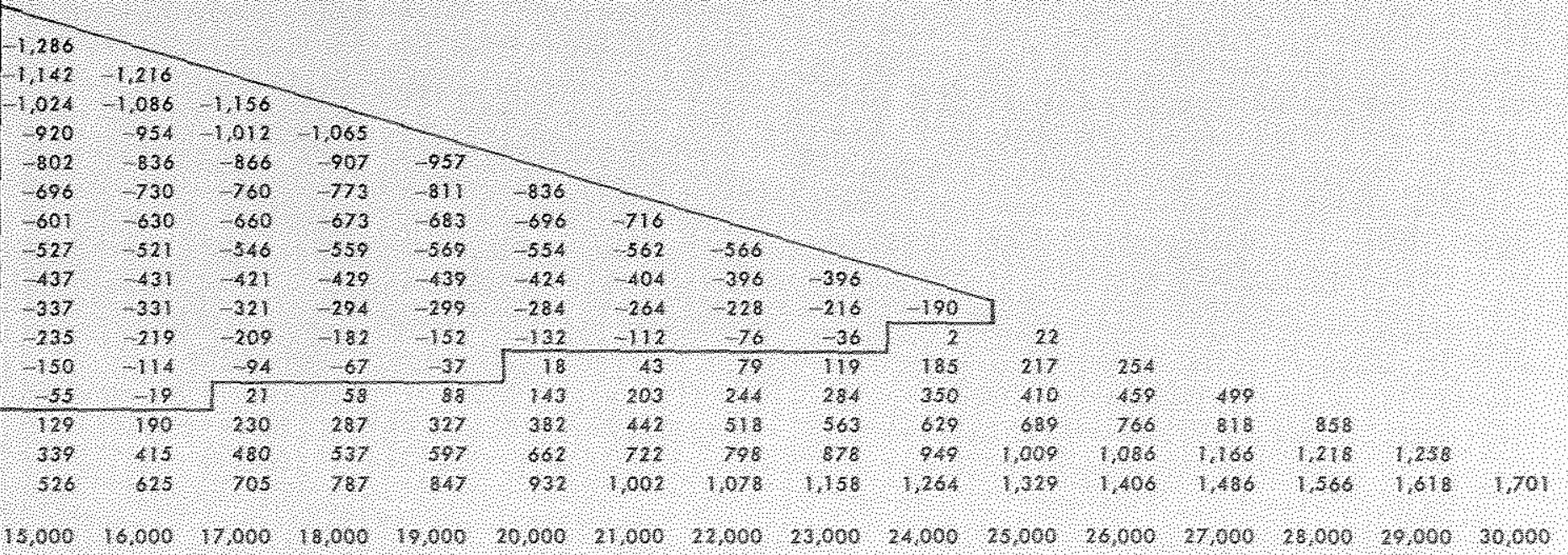

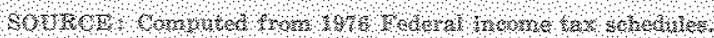

This reduces each of their AGr's to $\$ 14,250$, for a combined total of $\$ 28,500$. As married taxpayers, they can also deduct $\$ 750$ apiece as personal exempions, leaving a household AGI of 828,500 . Thus, the personal exemption has not contributed directy to ether a tax beneft or penaly on marrage.

Next, each single taxpayer can subtract the stand ard heduction equal to 16 percent of $A G T$, but not less thar $\$ 1,700$ or greater than $\$ 2,400$. As single taxpayer, 16 percent of John's AGI is $\$ 2,400$, the maximum allowablo standard dedvotion. Jane can diso deduct $\$ 2,400$ as a single taxpayer. If single, John and Jane each take standard deductons whok rotn $\$ 4,800$, lexving taxable momes of $\$ 11,850$ each (\$23,700 combined). In contrast, as marred taxpayers, their maximum allowable standard deduction is $\$ 2,800$ toring taxable income of $\$ 25,700$. Thus, the shadart leduction benefts the two taxpayers more when they are single then when they are married.

Naxt, the tax rates are applied to taxable income in order to deternine the tar liabily. It is important to note that there are four different tax rate schedules. 
Single taxpayers with dependents use the "head of household" tax schedule. Single people who do not qualify as a hoad of household must use the tax rates for single taxpayers. Married taxpayers may either fle a joint or separate return. The tax schedule for married taxpayers filing separately differs from the rates applied to single taxpayers. The "married separate" schedule applies "married joint" rates to half the income that would be taxed at each level on the "married joint" schedule. Consequently, the tax rate progression is much steeper on the "married separate" schedule. Unless one spouse has a large amount of tax preferred income, such as capital gains or medical expenses, a married couple usually minimizes their tax liability by filing a joint return.

John and Jane, as single taxpayers must pay taxes on $\$ 11,850$ of income each. This puts them in the 27 percent marginal bracket of the tax rate schedule for single taxpayers. Consequently, John and Jane each have tax liabilities of $\$ 2,583$ for a total of $\$ 5,166 .{ }^{10}$ As married taxpayers, John and Jane have $\$ 25,700$ of joint taxable income, which puts them in the 36 percent marginal tax bracket for martied taxpayers filing joint returns. Their joint tax liability is $\$ 6,272$ or $\$ 1,106$ more than their combined tax liabilities as single taxpayers. Thus, tax rates benefit two single taxpayers more than two married taxpayers. ${ }^{11}$

Finally, as single taxpayers John and Jane can each claim an individual tax credit equal to the greater of $\$ 35$ each or 2 percent of taxable income $(\$ 11,850$ apiece) limited to $\$ 180$. Thus, John and Jane are each entitled to reduce their tax liabilities by $\$ 180$, for a final tax of $\$ 2,403$ each or $\$ 4,806$ total. If John and Jane are married, their joint tax credit is limited to $\$ 180$, as opposed to $\$ 180$ each when single. Their final joint tax liability is $\$ 6,092$, which is $\$ 1,286$ greater than the combination of their single tax liabilities.

In summary, given the simplifying assumptions made above, the standard deduction, the tax rate schedules, and 1976 tax credits contribute to the additional Federal income taxes paid by married working taxpayers simply because of their marital status.

10These figures are taken from the 1976 Tax Table, which the IhS prepares. Since 1976 taxes are calculated over $\$ 50$ incone intervals for incomes less that $\$ 20,000$, the liablity is slightly lower, than if calculated from the tax rate schedules.

Whe fact that single taxpayers have less taxable income as a result of larger combined standard deductions does bias downward the applicable tax bracket. However, because the tax rate schedules differ hetween married and single taxpayers, tax rates still contribute to the generally lower tax liability for two single taxpayers, whose combined incomes equal a natried couple's joint income.

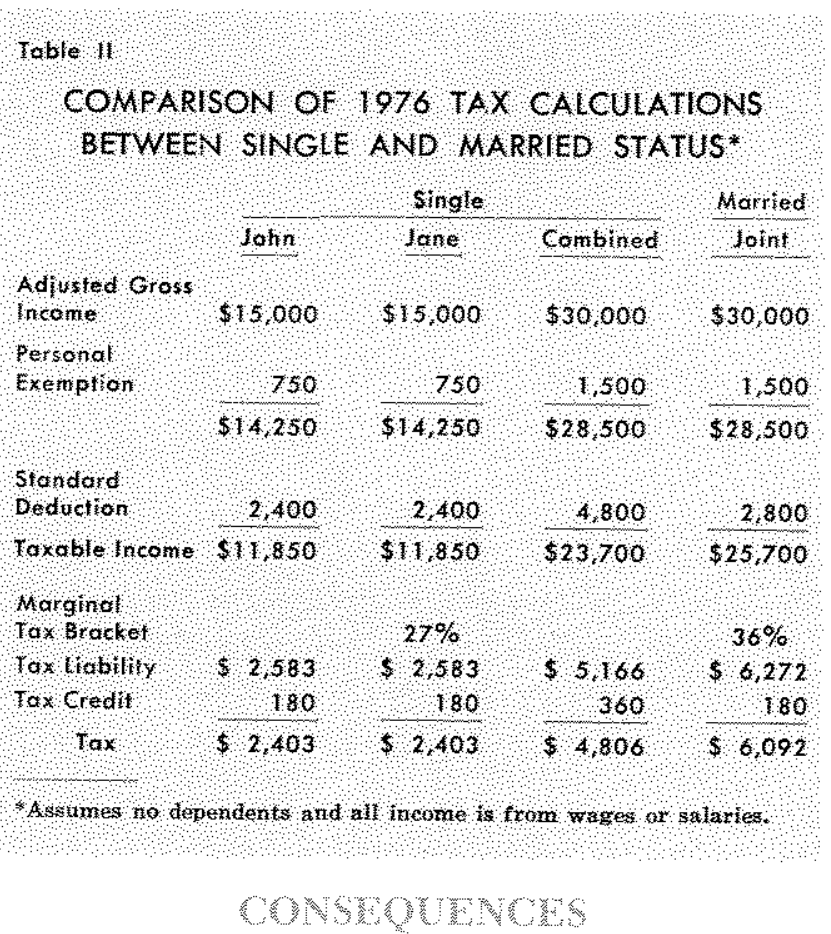

There are several impottant consequences of the tax penalty imposed on two married workers. One readily apparent effect of this differential tax treatment is that 1976 tax laws made it more expensive for two married people to work. The disincentive to work provided by tax laws affects the money standard of living which a household will achieve. If the tax laws make it more expensive to work, other things held constant, households will achieve a lower money income than would be otherwise possible.

The work disincentive of the tax laws is of particular importance in the decision of married women to enter the labor force. Since it is traditionally (but not always correctly) assumed that the husband is the primary breadwinner, the wife is typically considered to have greater latitude in deciding to enter the labor force. In making a rational decision to go to work, a wife would balance (either explicitly or implicitly) the added costs of going back to work, such as child care expenses, transportation costs, appropriate clothes, etc., against the additional income she will earn. The additional income will be her salary after taxes and other deductions. The tax penalty on married workers reduces her salary more than if she were single.

For example, if her husband makes $\$ 10,000$, the last dollar of his income is taxed at 19 percent, ${ }^{12}$ When

\footnotetext{
1+This figure assumes that the standard deduction is used, all income is derived from wages or salaries, and the married couple has no dependents and files a joint return.
} 
the wife goes to work, since her husband is already working and paying taxes, the first dollar of her income is taxed at 19 percent. That is, her income does not benefit from exemptions, deductions, or lower marginal tax rates applicable on initial amounts of income. Consequently, the tax structure has a negative influence on the labor force participation of married women. Of course, other factors can and have offset this influence, as evident from the increase in the labor force participation rate of married women in recent years.

Another effect of the disparity between the tax treatment of workers who are married and those who are single is an increase in Government revenue. The Government collects more taxes, under the circumstances outlined above, when two workers marry rather than remain single. In addition, when married workers receive cost-of-living adjustments, the Government also benefits, as mentioned earlier, since the extra tax liability on married workers increases as their incomes increase. Thus, the tax penalty on married workers makes the Government's deficit less than it would be otherwise.

A final consideration is that the differentiation of tax liability based only on marital status tends to undermine the equity which many people expect to find in the tax system. The less "just" a tax, the more incentive there is to find ways to avoid paying the tax, and this in turn reduces tax revenues or increases the cost of enforcing tax laws.

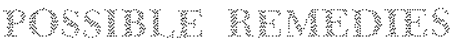

Considering the traditionally high value placed on marriage, family, and work in American society, it is likely that steps will eventually be taken to reduce the tax penalty imposed on married workers. The existence of this penalty is itself the result of previous Congressional actions which attempted to correct apparent inequities in the tax structure. Prior to 1948 , husbands and wives in community property states could each claim half of their household income for tax purposes, even if only one of the spouses actually earned all of the income. For example, if one spouse eamed $\$ 20,000$ and the other was not employed outside the home, each claimed $\$ 10,000$ of income. Given the progressively higher marginal tax rates, two incomes of $\$ 10,000$ were taxed less than one $\$ 20,000$ income. In noncommunity property states, this benefit was not available. A provision referred to as incomesplitting was added to the Federal income tax struc- ture in 1948 to make this benefit available to all married taxpayers. This was done by doubling the income ranges for married taxpayers associated with each tax rate. For example, if the first $\$ 500$ of income were taxed at 14 percent for a single person, the first $\$ 1,000$ of income for married couples would be taxed at 14 percent.

While the income-splitting provision extended tax benefits to married couples in all of the states, single taxpayers were now subject to much higher marginal tax rates than a married person making the same in come, but able to benefit from the income-splitting provision. Perceiving the harsher tax treatment of single people, lawmakers lowered the tax rates for singles in 1971. As Table III shows, prior to 1971, single taxpayers with the same taxable income (income after subtracting personal exemptions and deductions) as married taxpayers filing jointly could pay as much as 42 percent more taxes than a married couple. The 1971 rate changes for single taxpayers reduced this differential to 20 percent. In reducing rates for single taxpayers, however, a tax penalty for households in which both spouses are employed resulted.

Measures already enacted to change 1977 tax laws alter the standard deductions allowed single and married taxpayers, thereby partially reducing the tax penalty on married workers. In 1976 the maximum

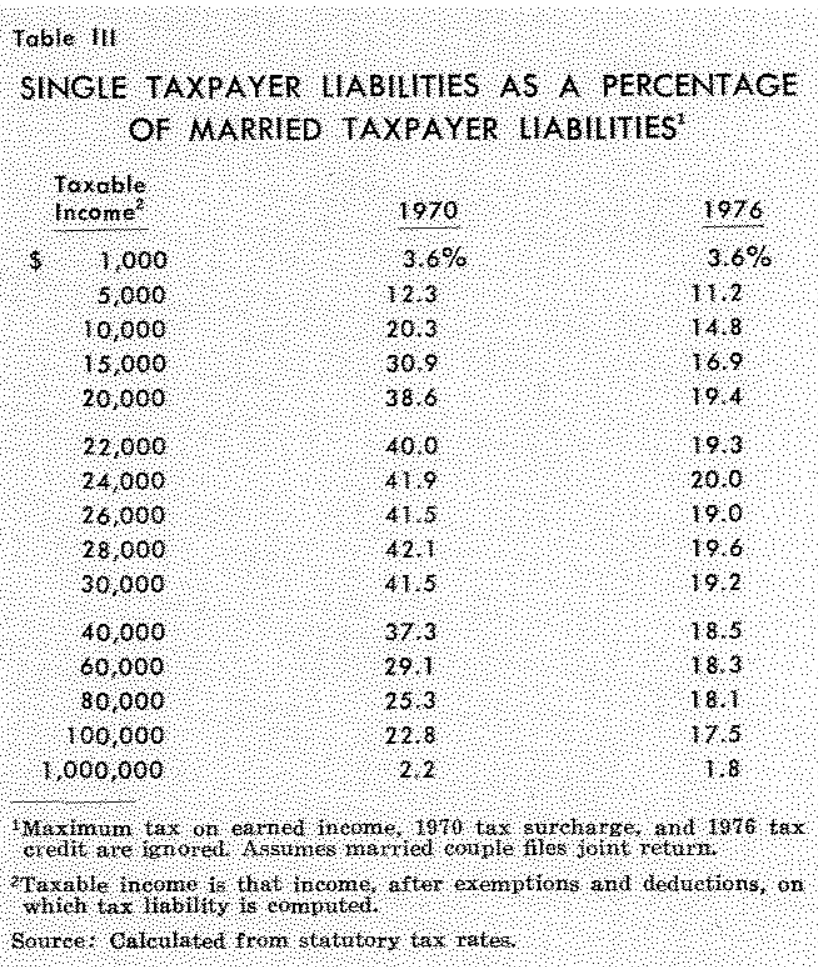


standard deduction was $\$ 2,800$ for a married couple and $\$ 4,800$ for two single workers, a $\$ 2,000$ difference. The 1977 law provides a $\$ 3,200$ standard deduction for joint returns and $\$ 2,200$ ( $\$ 4,400$ combined) for singles. This reduces the difference to $\$ 1,200 .^{13}$

Recent proposals by the Treasury Department call for a special tax deduction to be granted to families where both spouses work outside the home, to deal explicitly with the tax penalty on married workers. ${ }^{14}$ Under this proposal, the spouse with the lower income would be allowed to deduct 10 percent of the first $\$ 6,000$ of earnings. This proposal would benefit lower income couples relatively more than couples with higher incomes.

An alternative method, not included in the Treasury proposals, would completely eliminate the tax penaly on married workers. Married individuals who both work could be given the option of using the single tax rate schedule. Couples could compute their taxes using the "married joint," "married separate," and "single" schedules and use the status which minimizes their joint tax liability, with the provision that both spouses must use the same schedule.

13 Hankbook for Tax Reduction and Simplification Act of 1977 , Federal Taxes, Report Bullettn 25, Section 2 (Englewood Cliff, New Jersey: Prentice Hall, 1977), p. 5.

14David $\mathrm{E}$. Rosenblum, "Most Families Would Pay Less Under Tax Plan," Now York Times, September 30, $197 \%$.

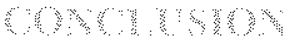

Two individuals, who both work, can be taxed more if they are married than if they are single. The more equal their incomes and the larger their incomes, the greater the tax penalty on married workers. The standard deduction, tax rate schedule, and individual tax credit provisions contributed to the greater tax liability for married couples in 1976. The tax penalty can be viewed as either a disincentive for working, single people to marry, or as a disincentive for married people to work. While Congressional intent has never shown an active interest in influencing such decisions, the tax structure imposes a tax penalty or benefit on households depending on the martal and employment status of the household members.

In a broader context, the tax penalty on married workers is illustrative of the complex and sometimes unintended consequences of tax provisions. Tax credits and reductions have been prescribed from time to time to "stimulate" the economy, reduce energy consumption, promote capital formation, and aid various other social and economic causes. While the intended objectives of these tax provisions may be worthwhile and laudable, the unintended consequences may be unacceptable and contrary to social values. The tax penalty on married workers illustrates the necessity of careful consideration of all of the possible consequences of tax proposals. 